\title{
Copper Supplementation of Young Cattle Grazing Improved Meadow Pastures in Southeastern Oregon
}

\author{
F.B. GOMM, P.H.WESWIG, AND R.J. RALEIGH
}

\begin{abstract}
Yearling cattle grazing improved, tall fescue-legume, meadow pastures showed signs of copper deficiency. Copper supplemented as injected Cuprin or as $\mathrm{CuSO}_{4}$-salt mix reduced the copper deficiency as expressed by blood plasma analyses and animal gains. Yearlings receiving $\mathrm{Cu}$ gained $0.10-0.31 \mathrm{~kg} / \mathrm{hd} / \mathrm{day}$ more than the checks. The methods of supplying the $\mathrm{Cu}$ were equally effective, but injections raised large lumps on some animals. The interrelationship of $\mathrm{Cu}$ and $\mathrm{Mo}$ and their relative concentrations in forage are important considerations in livestock nutrition. The forages grown on meadow soils in southeastern Oregon can cause signs that are associated with $\mathrm{Cu}$ deficiency in cattle. The sedges and rushes, dominant species in flood meadows, are less likely than grasses and legumes to cause $\mathrm{Cu}$ deficiencies because of favorable $\mathrm{Cu} / \mathrm{Mo}$ ratios. Of the species tested, tall fescue and white clover were most likely to cause deficiencies because of their relatively high concentrations of Mo.
\end{abstract}

For maximum livestock production, the diet must support a rate of gain that equals the animals' inherent potential. Yearlings that have the genetic potential for an average daily gain (ADG) of 1.5 may gain less if growth is limited by nutritional or management deficiencies. In that situation, operators who are satisfied with 0.5 $\mathrm{kg}$ ADG, may not realize that the forage is deficient or toxic in one or more nutrient elements. They may not recognize that under otherwise good management, low ADG is one of several signs that are related to unbalanced levels of nutrient elements.

Relatively small a mounts of certain elements, essential to animal health, often satisfy the requirement and increase production. Chemical analysis only of forage for individual elements, however, does not always detect the problem since forage availability and the ratio of two interacting elements may be more significant than the total concentration of either element alone. Copper $(\mathrm{Cu})$ and molybdenum $(\mathrm{Mo})$ are two such elements. Cattle grazing forages with Mo concentrations greater than $2 \mathrm{ppm}$ may exhibit $\mathrm{Cu}$ deficiency symptoms (molybdenosis) and respond to $\mathrm{Cu}$ supplementation. Young animals are usually more susceptible than adults, and cattle are more susceptible than sheep. Common signs of molybdenosis include faded hair coat, diarrhea, and low gains. Prolonged $\mathrm{Cu}$ deficiencies cause impaired reproduction, poorly coordinated muscular movement, skeletal abnormalities, and anemia (Dollahite et al. 1972).

In 1970-71, yearling cattle grazing newly developed improved meadow pastures in southeastern Oregon showed symptoms of $\mathrm{Cu}$ deficiency, including bleached hair, diarrhea, and $0.5 \mathrm{~kg} \mathrm{ADG}$. Heifers injected with copper glycinate gained $0.09 \mathrm{~kg} /$ day more than those that received no $\mathrm{Cu}$.

\footnotetext{
Authors are range scient ist, U.S.D.A. Agr. Res. Serv., Crops Research Laboratory, Utah State University, I ogan, Utah 84322, formerly at Oregon State University. Squaw Butte Agr. Exp. Sta., Burns, Ore.; professor, Department of Agricultura Chemistry, and superintendnet, Squaw Butte Agr. Exp. Sta.. Oregon State Univ.. respectively.

Cooperative investigations of the USDA. Agr. Res. Serv., and the Agricultura Experiment Station. Oregon State University. Technical Paper No. 5322 of the latter Manuscript received September 19, 1980.
}

In the present study, conducted from 1972 to 1976, we determined the comparative effects of supplementing $\mathrm{Cu}, \mathrm{Zinc}(\mathrm{Zn})$ and trace mineral mixtures on gains of yearling cattle grazing improved meadow pastures.

\section{Study Area and Procedures}

Pastures were located on a flood meadow plain of the Squaw Butte Exp. Sta., Section 5 winter headquarters, about $10 \mathrm{~km}$ southeast of Burns, Ore. Improved pastures, developed from previously wild-flood meadows, were planted to mixtures of tall fescue (Festuca arundinacea Schreb.), Fawn variety and alfalfa (Medicago sativa L.), Vernal variety; and tall fescue and white clover (Trifolium repens $\mathrm{L}$.), Ladino variety. The soil, tentatively classified as Silvies series, Fluventic and Cumulic Haplaquoll, was developed from lacustrine sediments related to an old lake bed and alluvium deposits. The organic matter content of the soil was relatively high, as much as $17 \%$ in the upper $30-\mathrm{cm}$ profile, and the $\mathrm{pH}$ ranged from 7.3 to 8.7 . In its natural state, the site was a wetland meadow subjected to seasonal flooding and high water table.

In 1972, 6 yearling heifers were assigned to each of 4 mineral supplement treatments and each of the 2 pasture mixtures. Supplement treatments were: (1) salt, (2) copper sulfate $\left(\mathrm{CuSO}_{4}\right)$ with salt, (3) zinc oxide $\left(\mathrm{ZnO}_{2}\right)$ and $\mathrm{CuSO}_{4}$ with salt, and (4) trace minerals with salt. Bonemeal was also available free choice separate from the supplement. Mineral supplements, which were mixed with the salt and provided free choice, we re calculated to provide salt intake at $20 \mathrm{~g} / \mathrm{hd} /$ day, $\mathrm{CuSO}_{4}$ at $1 \mathrm{~g} /$ day $(5 \%)$, and $\mathrm{ZnO}_{2}$ at $100 \mathrm{mg} /$ day $(0.05 \%)$. Trace minerals were mixed with salt to provide 1 $\mathrm{g} / \mathrm{hd} /$ day $(5 \%)$. Trace minerals by percent of mix were: $\mathrm{Zn} 29.6 . \mathrm{Fe}$ 9.8, Mn 8.0, Cu 3.0, S 3.0, I 0.18. Co 0.06, and Ca 3 to 5.

In 1973, 16 yearling heifers grazing tall fescue-alfalfa pastures received $\mathrm{CuSO}_{4}$ in their salt; and 16 received no $\mathrm{Cu}$. In each group, however, 8 heifers were injected at the beginning of the season with $2 \mathrm{cc}$ of Cuprin per a nimal. In 1974, 12 yearling heifers on each of 2 pasture mixtures (tall fescue-alfalfa and tall fescue-clover) and 2 rotational grazing systems ( 7 days grazing in 28 days and 14 days grazing in 28 days) received $\mathrm{Cu}$ in their salt, and 12 received no $\mathrm{Cu}$. In 1972, 1973, and 1974, blood samples for 6 to 8 animals in each of the independent variable groups were analyzed for plasma $\mathrm{Cu}$ and whole blood $\mathrm{Zn}$ concentrations. Blood samples were taken at the beginning of and at 28-day intervals throughout the grazing season. The blood samples were analyzed by the Department of Agriculture Chemistry, Oregon State University.

All cattle used in the experiment were yearling replacement heifers of the Squaw Butte Experiment Station. They were weighed at the beginning and end of the grazing season after overnight shrinking from feed and water. During the grazing season they were weighed at 28-day intervals without overnight shrinkage.

Forage samples taken from pastures and from selected alfalfa. grass, and meadow plants were analyzed for $\mathrm{Cu}, \mathrm{Mo}, \mathrm{Mn}, \mathrm{Zn}, \mathrm{P}$, $\mathrm{Ca}, \mathrm{Mg}, \mathrm{K}$, and $\mathrm{Co}(\mathrm{Gomm}, \mathrm{F}$.B. unpublished data). Analyses for plant zinc, manganese, potassium, calcium, and magnesium were 
Table 1. Beef gains from improved meadow pastures as affected mineral supplements, 19721.

\begin{tabular}{|c|c|c|c|c|c|}
\hline Mineral supplements & $\begin{array}{l}\text { Animals/ha } \\
\text { (no.) }\end{array}$ & $\begin{array}{l}\text { Average initial } \\
\text { weight } \\
(\mathrm{kg})\end{array}$ & $\begin{array}{c}\text { Total } \\
\text { gain/ha } \\
(\mathrm{kg})\end{array}$ & $\begin{array}{c}\text { Average } \\
\text { beef gain } \\
(\mathrm{kg})\end{array}$ & $\begin{array}{l}\text { Average daily } \\
\text { gain } \\
(\mathrm{kg})\end{array}$ \\
\hline \multicolumn{6}{|c|}{ Tall fescue-alfalfa pastures } \\
\hline Check $^{2}$ & 7.4 & 213 & 625 & 84 & $0.76 \mathrm{a}^{4}$ \\
\hline Copper & 7.4 & 208 & 744 & 100 & $0.91 \mathrm{~b}$ \\
\hline Copper-zinc & 8.6 & 198 & 820 & 95 & $0.86 \mathrm{~b}$ \\
\hline Trace minerals ${ }^{3}$ & 8.6 & 213 & 807 & 94 & $0.85 b$ \\
\hline \multicolumn{6}{|c|}{ Tall fescue-white clover pastures } \\
\hline Check $^{2}$ & 7.4 & 212 & 597 & 81 & $0.74 a$ \\
\hline Copper & 7.4 & 212 & 676 & 91 & $0.83 b$ \\
\hline Copper-zinc & 8.6 & 201 & 816 & 95 & $0.86 \mathrm{~b}$ \\
\hline Trace minerals ${ }^{3}$ & 8.6 & 224 & 796 & 93 & $0.84 b$ \\
\hline
\end{tabular}

'All pastures were grazed by yearlings for 112 days.

${ }^{2}$ Check treatment received salt and bonemeal ad libitum.

3Trace minerals by percent of mix were $\mathrm{Zn} 29.6, \mathrm{Fe} 9.8, \mathrm{Mn} 8.0, \mathrm{Cu} 3.0, \mathrm{~S} 3.0,10.18, \mathrm{Co} 0.06$, and $\mathrm{Ca} 3$ to 5 .

${ }^{4} \mathrm{ADG}$ values followed by different letters are significantiy different at $P<.05$.

made on $\mathrm{HClO}_{4}-\mathrm{HNO}_{3}$ digests by atomic absorption spectrophotometry (Perkin-Elmer Model 306) at standard instrument settings found in the 1971 Perkin-Elmer Manual, Analytical Methods of Absorption.' Phosphorus concentrations were colorimetrically determined from $\mathrm{HClO}_{4}-\mathrm{HNO}_{3}$ digests using ammonium vanadatemolybdate color forming reagent. Total $\mathrm{N}$ was determined using a modified micro-Kjeldahl procedure. Copper concentrations were determined by the standard flame method of atomic absorption spectrophotometry. Molybdenum and cobalt concentrations were determined by atomic absorption with the Perkin-Elmer Model 306 in conjunction with a Perkin-Elmer HGA70 Heated Graphite Atomizer.

\section{Animal Gains}

\section{Results and Discussion}

In 1972, the response to dietary supplements was positive (Table 1). Animals in all $\mathrm{Cu}$ supplemented groups gained 0.10 to 0.15 $\mathrm{kg} / \mathrm{hd} /$ day more than the controls. The addition of $\mathrm{Zn}$ gave no additional increase in ADG.

In 1973, animals receiving $\mathrm{Cu}$ averaged $0.19 \mathrm{~kg} / \mathrm{hd} /$ day more than those that received no $\mathrm{Cu}$ (Table 2). The method of supplying the $\mathrm{Cu}$ did not significantly affect ADG. In some animals, however. large lumps developed in the area of the injection.

In 1974, (data not shown) the yearling heifers that received the $\mathrm{Cu}$ supplement continued to gain 0.1 to $0.2 \mathrm{~kg} / \mathrm{hd} /$ day more than those that received only salt.

\section{Blood Copper}

Analysis of blood samples showed no consistent trend for $\mathrm{Zn}$

Mention of a trademark does not constitute an endorsement of the product to the exclusion of other products that may be suitable. levels with a range of 2.5 to $9.1 \mathrm{ppm}$, except that in $1974, \mathrm{Zn}$ levels generally decreased as the season advanced (Table 3). During the first month on pasture, however, blood-Cu decreased markedly in animals that received no $\mathrm{Cu}$. The $\mathrm{Cu}$ level continued to decline in the second month but at a slower rate until it leveled at 0.21 to 0.24 ppm. The blood-Cu level in animals that received $\mathrm{Cu}$ increased to 0.8 ppm by early June, 1973, and remained near that level through the season (Table 3 ). The blood-Cu level also increased with $\mathrm{Cu}$ supplementation in 1974 but not as markedly as it did in 1973. The normal blood plasma level of $\mathrm{Cu}$ should be about $1.0 \mathrm{ppm}$.

\section{Forage Nutrients}

Analyses of forage from the meadow pastures indicated not major mineral problem other than $\mathrm{Cu}$ and $\mathrm{Mo}$ (unpublished data). All forages appeared to be borderline or slightly deficient in meeting the animal's requirement for $\mathrm{Cu}$. Mo apparently was within the normal range in the grasses, but was high in the legumes. In forage samples from other sites in southeastern Oregon, $\mathrm{Cu}$ was deficient in grass and meadow hays (Table 4). The $\mathrm{Cu}$ concentrations in alfalfa were within the recommended allowance for cattle, but the Mo levels were high. In sedges, the Mo levels were relatively low. For diagnostic criteria in forages, Lesperance (1967) suggested use of the followng levels of $\mathrm{Cu}$ and $\mathrm{Mo}$ :

$\begin{array}{lll} & \text { Cu ppm } & \text { Mo ppm } \\ \text { Copper deficient } & 0.1-5.0 & 0.1-5.0 \\ \text { Normal } & 5-15 & 1-5 \\ \text { Molybdenum toxic } & 5-8 & 5-50\end{array}$

The $\mathrm{Cu} / \mathrm{Mo}$ ratio apparently is as important as elemental levels and should be greater than 2 (Clawson et al. 1972, Dye and O'hara 1959, Mylrea 1958, Miltimore et al. 1973). When the ratio is less than 2, regardless of the $\mathrm{Cu}$ concentration, molybdenosis is proba-

Table 2. Summary of beef gains from improved tall fescue-alfalfa pastures as affected by grazing schedule and mineral supplements, 1973.

\begin{tabular}{|c|c|c|c|c|c|}
\hline Mineral supplements & $\begin{array}{c}\text { Animals/ha } \\
\text { (no.) }\end{array}$ & $\begin{array}{c}\text { Average initial } \\
\text { weight } \\
\text { (kg.) }\end{array}$ & $\begin{array}{c}\text { Total } \\
\text { gain/ha } \\
(\mathrm{kg})\end{array}$ & $\begin{array}{c}\text { Average } \\
\text { beef gain } \\
(\mathrm{kg})\end{array}$ & $\begin{array}{c}\text { Average } \\
\text { daily gain } \\
(\mathrm{kg})\end{array}$ \\
\hline \multicolumn{6}{|c|}{ Pastures grazed for 7 days with 21 days recovery } \\
\hline Check' & 8 & 216 & 639 & 80 & $0.73 \mathrm{a}^{2}$ \\
\hline Copper in salt & 8 & 177 & 731 & 91 & $0.83 \mathrm{~b}$ \\
\hline Copper injected & 8 & 215 & 688 & 86 & $0.78 \mathrm{ab}$ \\
\hline Copper in salt and injected & 8 & 217 & 785 & 98 & $0.89 \mathrm{~b}$ \\
\hline \multicolumn{6}{|c|}{ Pastures grazed for 14 days with 14 days recovery } \\
\hline Check $^{1}$ & 8 & 216 & 751 & 94 & $0.85 b$ \\
\hline Copper in salt & 8 & 215 & 953 & 119 & $1.08 \mathrm{c}$ \\
\hline Copper injected & 8 & 219 & 1,027 & 128 & $1.16 \mathrm{c}$ \\
\hline Copper in salt and injected & 8 & 197 & 912 & 114 & $1.04 \mathrm{c}$ \\
\hline
\end{tabular}

Check treatment received salt and bonemeal ad libitum.

${ }^{2} \mathrm{ADG}$ values followed by different lettters a re significantly different at $P<.05$. 
Table 3. Copper and zinc levels in blood from animals grazing irrigated pastures.

\begin{tabular}{|c|c|c|c|c|c|c|}
\hline \multirow[b]{2}{*}{ Mineral treatment } & \multicolumn{6}{|c|}{ Concentration of $\mathrm{Cu}$ and $\mathrm{Zn}$ in ppm by dates } \\
\hline & $4 / 8$ & $6 / 3$ & $7 / 1$ & $7 / 29$ & $8 / 12$ & $8 / 22$ \\
\hline \multicolumn{7}{|c|}{ Plasma copper level } \\
\hline \multicolumn{7}{|l|}{ Check: } \\
\hline 1973 & 0.75 & 0.39 & 0.24 & 0.26 & - & 0.21 \\
\hline 1974 & 0.72 & 0.58 & 0.56 & 0.44 & 0.33 & 0.24 \\
\hline \multicolumn{7}{|c|}{ Copper sulfate with salt: } \\
\hline 1973 & 0.77 & 0.81 & 0.73 & 1.00 & 一 & 0.88 \\
\hline $1974 !$ & 0.66 & 0.61 & 0.71 & 0.79 & 0.75 & 0.74 \\
\hline \multicolumn{7}{|c|}{ Whole blood zinc level } \\
\hline \multicolumn{7}{|l|}{ Check: } \\
\hline 1973 & 4.0 & 5.6 & 3.2 & 9.1 & - & 4.2 \\
\hline 1974 & 5.4 & 4.2 & 3.9 & 3.1 & 3.2 & 2.5 \\
\hline \multicolumn{7}{|c|}{ Copper sulfate with salt } \\
\hline 1973 & 3.9 & 5.4 & 2.8 & 8.0 & - & 3.9 \\
\hline $1974^{\prime}$ & 5.5 & 4.0 & 4.2 & 3.1 & 3.3 & 2.6 \\
\hline
\end{tabular}

'Salt was mixed with bonemeal until June 15; after June 15 bonemeal was fed ad libitum free of salt.

ble. Nutritive $\mathrm{Cu}$ requirements for cattle appear to be about $0.05 \mathrm{~g}$ per day. Beeson (1965) suggested that feed should contain $10 \mathrm{ppm}$ of $\mathrm{Cu}$ when the Mo content is $1 \mathrm{ppm}$. According to the National Research Council (1970) beef cattle requirements for $\mathrm{Cu}$ are met with rations containing 4-7 ppm when the levels of $\mathrm{Mo}$ and $\mathrm{SO}_{4}$ are low; in areas where the Mo level is high, the $\mathrm{Cu}$ requirement may be 2-3 times as great. Dollahite et al. (1972) suggested that the ideal $\mathrm{Cu} / \mathrm{Mo}$ ratio is $6: 1$ and that a ratio of less than $1: 2$ always causes $\mathrm{Cu}$ deficiencies. When the Mo concentration is as much as $10 \mathrm{ppm}$, even normal $\mathrm{Cu}$ levels may not prevent trouble.

The exact role of Mo in lowering the biochemical availability of
$\mathrm{Cu}$ in animals is not known. The formation of lingren, a Mo-Cu complex, during metabolic processes, however, has been suggested as a mechanism that impairs $\mathrm{Cu}$ availability (Dowdy and Matrone 1968). For the purpose of this report, it is sufficient that Mo levels as low as $2.0 \mathrm{ppm}$ in forage antagonize $\mathrm{Cu}$ metabolism and cause illness (Pope 1971 and Dollahite et al. 1972).

Average concentrations of $\mathrm{Cu}$ and $\mathrm{Mo}$ in various forage species from the study site showed that the grasses were $\mathrm{Cu}$ deficient (Table 5). The legumes, sedges, and rushes were higher in $\mathrm{Cu}$ than the grasses, but the legumes, especially white clover, also were high in Mo. Mo concentrations in the sedges and rushes were relatively

Table 4. Average elemental concentrations in forages harvested for hay in southeastern Oregon, 1946-1970.

\begin{tabular}{|c|c|c|c|c|c|c|c|c|c|c|}
\hline \multirow[b]{2}{*}{ Forage type } & \multirow{2}{*}{$\begin{array}{l}\text { Location } \\
\text { samples }\end{array}$} & \multicolumn{4}{|c|}{$\%$} & \multicolumn{5}{|c|}{$\mathrm{ppm}$} \\
\hline & & $\mathrm{N}$ & $\mathbf{P}$ & $\mathrm{Ca}$ & $\mathrm{Mg}$ & $\mathrm{Mn}$ & $\mathrm{Fe}$ & Co & $\mathrm{Cu}$ & Mo \\
\hline Alfalfa hay Ist cutting & 5 & 2.4 & 0.25 & 1.22 & 0.29 & 42 & 101 & 0.22 & 8.0 & 4.4 \\
\hline Alfalfa hay 2 nd cutting & 4 & 2.4 & 0.23 & 1.21 & 0.25 & 30 & 311 & 0.19 & 8.7 & 8.0 \\
\hline $\begin{array}{l}\text { Alfalfa hay } 3 \text { rd cutting } \\
\text { Alfalfa chop: }\end{array}$ & 3 & 2.7 & 0.22 & 2.02 & - & - & 220 & 0.11 & 9.1 & 9.2 \\
\hline Ist cutting & 1 & 1.8 & 0.22 & 1.00 & - & - & 585 & 0.29 & 6.0 & - \\
\hline 2nd cutting & 1 & 1.9 & 0.20 & 1.03 & - & - & 625 & 0.37 & 6.3 & - \\
\hline Grass hay & 5 & 1.1 & 0.12 & 0.77 & - & 214 & 70 & 0.04 & 4.5 & 2.8 \\
\hline Meadow hay & 3 & 1.1 & 0.12 & 0.72 & - & 206 & 81 & 0.05 & 2.3 & 2.7 \\
\hline Sedge hay & 4 & 1.4 & 0.17 & 0.93 & - & 240 & 96 & 0.07 & 3.3 & - \\
\hline Rusty sedge & 3 & 1.6 & 0.18 & 0.23 & - & - & 117 & 0.15 & 5.2 & 2.1 \\
\hline
\end{tabular}

Table 5. Concentration and occurrence of copper and molybdenum in some forage species grown on high organic meadow soils.

\begin{tabular}{|c|c|c|c|c|c|c|c|c|}
\hline \multirow[b]{3}{*}{ Forage species } & \multirow{3}{*}{$\begin{array}{l}\text { Samples } \\
\text { tested }\end{array}$} & \multicolumn{7}{|c|}{ Elemental concentrations in herbage } \\
\hline & & \multicolumn{3}{|c|}{ Copper ppm } & \multicolumn{3}{|c|}{ Molybdenum ppm } & \multirow{2}{*}{$\begin{array}{l}\mathrm{Cu} / \mathrm{Mo} \\
\text { Mean }\end{array}$} \\
\hline & & Mean & Range & $\mathrm{SE}$ & Mean & Range & $\mathrm{SE}$ & \\
\hline Tall fescue & 30 & 2.6 & $0.2-6.7$ & 1.7 & 2.8 & $0.4-9.2$ & 1.9 & 0.9 \\
\hline Intermediate wheatgrass & 10 & 3.3 & $0.9-8.0$ & 2.5 & 2.0 & $0.5-3.2$ & 1.0 & 1.6 \\
\hline Beardless wildrye & 15 & 4.3 & $0.6-6.0$ & 1.8 & 3.0 & $1.1-7.3$ & 1.9 & 1.4 \\
\hline Smooth bromegrass & 5 & 3.9 & $2.5-7.0$ & 1.6 & 3.7 & $0.8-7.9$ & 2.5 & 1.1 \\
\hline Alfalfa & 66 & 8.7 & $3.0-18.0$ & 2.1 & 10.2 & $3.9-15.0$ & 4.0 & 0.8 \\
\hline White clover & 6 & 5.6 & $5.0-10.4$ & 0.5 & 22.4 & $15.8-37.5$ & 5.8 & 0.2 \\
\hline Sainfoin & 3 & 5.2 & $4.4-14.4$ & 0.6 & 14.5 & $12.0-17.2$ & 2.1 & 0.3 \\
\hline Sedges & 20 & 4.9 & $2.0-9.2$ & 2.1 & 2.3 & $0.7-4.7$ & 1.2 & 2.2 \\
\hline Rushes & 5 & 5.3 & $3.0-7.4$ & 1.9 & 1.4 & $0.9-1.7$ & 0.3 & 3.8 \\
\hline
\end{tabular}

'Mention of a trademark does not constitute an endorsement of the product to the exclusion of other products that may be suitable. 
low. Consequently, The $\mathrm{Cu} / \mathrm{Mo}$ ratios were less than 2 in grasses and legumes and greater than 2 in sedges and rushes.

At the beginning of the grazing season (Table 3), the blood level of $\mathrm{Cu}$ was subnormal, indicating that $\mathrm{Cu}$ level in the winter feed (meadow hay) did not meet the nutritive requirement. Because meadow hay contains a large percentage of sedges and rushes, however, the low level of Mo could have kept the $\mathrm{Cu} /$ Mo ratio greater than 2 and moderated the severity of the $\mathrm{Cu}$ deficiency associated with the meadow hay.

The subsequent grazing of tall fescue-alfalfa and tall fescueclover pastures with unfavorable $\mathrm{Cu} / \mathrm{Mo}$ ratios apparently further decreased the blood- $\mathrm{Cu}$ levels. As a result of the low blood- $\mathrm{Cu}$, animals showed signs of $\mathrm{Cu}$ deficiency, including low ADG, diarrhea, and faded hair color.

\section{Conclusions}

Dietary $\mathrm{Cu}$ and Mo, which are essential to animals, are antagonists, and proportions as well as amounts should be controlled. When the $\mathrm{Cu} / \mathrm{Mo}$ ratio is below 2, signs of molybdenosis may appear. Because signs of $\mathrm{Cu}$ deficiency and molybdenosis are almost identical and each condition can be successfully prevented and treated with $\mathrm{Cu}$ supplementation, molybdenosis is essentially a manifestation of $\mathrm{Cu}$ deficiency (Dollahite et al. 1972).

Copper deficiencies are widely distributed throughout the western United States. Areas of high Mo are located in parts of Washington, Oregon, California, Idaho, Nevada, Montana, Wyoming, and Colorado (Kubota 1975). Problem areas are associated with wet flood plains and alluvial fans. Copper deficiencies are most common in areas where forage is grown on soils of high $\mathrm{pH}$ that are high in organic matter. Such conditions exist in old lake beds and areas that are repeatedly flooded.

Supplemental $\mathrm{Cu}$ was administered as effectively to cattle in dietary mineral mixtures as by injection. Mineral mixtures, however, might be preferable because injection raised objectionable lumps. Regardless of the method used, $\mathrm{Cu}$ supplements alleviated the signs of $\mathrm{Cu}$ deficiency and increased beef production from the improved meadow pastures.

Pastures could be fertilized with $\mathrm{CuSO}_{4}$ at $5-10 \mathrm{~kg} /$ ha but at present direct treatment of the animal appears to be more practical. Animals that are grazing deficient pastures could either be injected with $2 \mathrm{ml}$ copper glycinate every 3 to 6 months (Clawson et al. 1972) or fed the following supplement, developed by Fisher et al. (1976) that supplies $1 \mathrm{~g} \mathrm{CuSO}_{4}$ per head with a daily consumption of $0.07 \mathrm{~kg}$ : ground barley, $25 \mathrm{~kg}$; salt, $15 \mathrm{~kg}$; bonemeal, $10 \mathrm{~kg} /$ and finely ground $\mathrm{CuSO}_{4}, 0.6 \mathrm{~kg}$.

\section{Literature Cited}

Beeson, W.M. 1965. Trace mineral needs of livestock. Western Feeds, January.

Clawson, W.J., A.L. Lesperance, V.R. Bohman, and D.C. Layhee. 1972. Interrelationship of dietary molybdenum and copper on growth and tissue composition of cattle. J. Anim. Sci. 34:516-520.

Dollahite, J.W., L.D. Rowe, L.M. Cook, D. Hightower, E.M. Mailey, and J.R. Kyzar. 1972. Copper deficiency and molybdenosis intoxication associated with grazing near a uranium mine. The Southwest Veterinarian 26:47-50.

Dowdy, R.P., and G. Matrone. 1968. A copper-molybdenum complex: its effects and movement in the piglet and sheep. J. Nutrition 95:179-201.

Dye, W.B., and J.L. O'Hara. 1959. Molybdenosis. Nevada Agr. Exp. Sta. Bull. 208.

Fisher, G.L., C.A. Hjerpe, and C.W. Qualls. 1976. Effects of dietary molybdenum on the metabolism of copper and molybdenum in young cattle. Bioinorg. Chem. 6:11-28.

Kubota, J. 1975. Areas of molybdenum toxicity to grazing a nimals in the western United States. J. Range Manage. 28:252-256.

Lesperance, A.L. 1967. Winning the battle against molybdenosis. Nevada Ranch and Home Rev. 3:14.

Miltimore, J.E., J.L. Mason, J.M. McArthur, C.C. Strachan, and J.B. Clapp. 1973. Response from copper and selenium with vitamin $E$ injections to cattle pastured on mineral and organic groundwater soils. Can. J. Anim. Sci. 53:237-244.

Mylrea, P.J. 1958. Copper-molybdenum-sulfate-manganese interaction and the copper status of cattle. Australian J. Agr. Res. 9:373-384.

National Research Council. 1970. Nutrient requirements of beef cattle. 4th revised edition.

Pope A.L. 1971. A review of recent mineral research with sheep. J. Anim. Sci. 33:1332-1343. 